\title{
Accountability Analysis in the Implementation of Employees Performance in Kanreg II BKN Surabaya
}

\author{
Sri Wahyuni \\ Faculty of Social and Political Sciences, Hang Tuah University \\ Surabaya Indonesia \\ Ikadona Aliyaturrahma \\ Faculty of Social and Political Sciences, Hang Tuah University \\ Surabaya Indonesia
}

\begin{abstract}
The research aims to analyze administrative and professional accountability in the implementation of employees performance in Kanreg II BKN Surabaya. There are two elements in the implementation of employees performance, namely Employee Work Targets and Work Behavior. Antonio Bar Cendon (1999), states that there are four forms of accountability typology, namely a) Political Accountability b) Administrative Accountability c) Professional Accountability d) Accountability for Democracy. The research uses descriptive qualitative method that focuses on operational principle, internal accountability, external accountability, subject matter, criteria, mechanism, and consequences. Data collection technique is done by observation, interviews, and documentation. The results of the analysis of administrative and professional accountability in implementing employees performance in Kanreg II BKN Surabaya are more dominant type of administrative and professional accountability, that can be seen from the sub-indicator of the dominant type of administrative accountability. The research is inseparable from the supporting factors, namely regulation, supervision, application systems, description of main tasks and functions, rewards, and sanctions.
\end{abstract}

Keywords: Accountability, Employees Performance, Kanreg II BKN Surabaya

\section{INTRODUCTION}

In order to implement the goal of the Indonesia nation, this country requires the human resources of Aparatur Sipil Negara (ASN) that is professional, neutral integrity, and free from corruption, collusion, and nepotism. According to Azhari (2011:12), the state bureaucracy must be directly involved in producing public goods and services that are needed by the people, therefore, the government bureaucracy is demanded to be responsive, transparent and accountable to various issues that develop in human life whether in politic, economy, social and culture (Sedarmayanti, 2012: 2-3).

In line with this, (Prasojo and Kurniawan, 2008: 2) also state that the basic foundation of bureaucratic reform must be started with the reform of the management of Human Resources that has been regulated in Law No. 5 Year 2014 concerning Aparatur Sipil Negara (ASN), that has high integrity and free from corruption, collusion, and nepotism.

It is expected that Law No. 5 Year 2014 gives some changes in the management of human resources and capacity development of employees in Indonesia that have an impact on $A S N$ performance measured annually on an individual basis and a payroll system based on workload provided in accordance with Government Regulation No. 46 Year 2011 concerning the Performance Evaluation of Civil Servants' Work Performance and Regulation of the Head of 
the National Civil Service Agency (BPN) No. 1 Year 2013 concerning the Compilation of Employee Work Targets (SKP) in ASN work performance assessment.

The obligation to prepare SKP based on several survey results on October 9, 2018 in Kanreg II BKN Surabaya, showed that there were weaknesses in the implementation of SKP that included the following issues: (1) Employees in carrying out their duties are not in accordance with the main tasks and functions of the established regulations. (2) Employees do not prepare SKP which is not consistent with the taxonomy and level. (3) The actual writing of unit in SKP must be written as report, however, the employees write them as data or notes. Based on these problems, the existence of SKP is a form of accountability. So that researchers see from the perspective of Antonio Bar Cendon (1999) which states there are four dimensions of accountability.

The research problem is how the administrative and professional accountability in the implementation of SKP in Kanreg II BKN Surabaya is conducted. Meanwhile, the purpose of the research is to describe and analyze administrative and professional accountability in the implementation of SKP in Kanreg II BKN Surabaya.

\section{CONCEPTUAL BASE}

Referring to the typology of accountability according to Antonio Bar Cendon (1999: 24-35) which is divided into four forms; political accountability, the actions that follow the program provisions and political values adopted by the government; administrative accountability, an action that is highly fulfilled by the legality of rules and procedures; professional accountability, actions that are very fulfilled with technical and practical rules in accordance with the profession being carried out; democratic accountability, actions that refer to the needs and interests of the wider social group or community. For this reason, the characteristics of each type of accountability can be mapped in table 1 . 
Table 1: Characteristics of Accountability (Antonio Bar Cendon, 1999)

\begin{tabular}{|c|c|c|c|c|}
\hline & Political Accountability & $\begin{array}{l}\text { Administrative } \\
\text { Accountability }\end{array}$ & $\begin{array}{c}\text { Professional } \\
\text { Accountability }\end{array}$ & $\begin{array}{c}\text { Democratic } \\
\text { Accountability }\end{array}$ \\
\hline $\begin{array}{l}\text { The basis } \\
\text { principal of } \\
\text { operational }\end{array}$ & $\begin{array}{l}\text { The actions that follow the } \\
\text { program provisions and } \\
\text { political values adopted by } \\
\text { the government }\end{array}$ & $\begin{array}{l}\text { The actions that is } \\
\text { highly fulfilled by the } \\
\text { legality of rules and } \\
\text { procedures }\end{array}$ & $\begin{array}{l}\text { The actions that are } \\
\text { very fulfilled with } \\
\text { technical and practical } \\
\text { rules in accordance } \\
\text { with the profession } \\
\text { being implemented }\end{array}$ & $\begin{array}{l}\text { The actions that refer } \\
\text { to the needs and } \\
\text { interests of the wider } \\
\text { social group or } \\
\text { community. }\end{array}$ \\
\hline $\begin{array}{l}\text { To whom internal } \\
\text { accountability is }\end{array}$ & Higher political authority & $\begin{array}{l}\text { 1. Higher political } \\
\text { authority } \\
\text { 2. The authority of } \\
\text { higher } \\
\text { administrative } \\
\text { institution }\end{array}$ & $\begin{array}{l}\text { 1. The authority of } \\
\text { higher professional } \\
\text { institution (technical } \\
\text { evaluation) } \\
\text { 2. The authority of } \\
\text { higher administrative } \\
\text { institution } \\
\text { (administrative } \\
\text { evaluation) }\end{array}$ & \\
\hline $\begin{array}{l}\text { To whom } \\
\text { external } \\
\text { accountability is }\end{array}$ & Regional parliament & $\begin{array}{l}\text { 1. Supervision and } \\
\text { control by external } \\
\text { institution } \\
\text { 2. Society as a subject } \\
\text { 3. Law and justice } \\
\text { institutions }\end{array}$ & $\begin{array}{l}\text { supervision and } \\
\text { control by external } \\
\text { institutions } \\
\text { (administrative } \\
\text { evaluation) }\end{array}$ & $\begin{array}{l}\text { 1. Social group } \\
\text { 2. Social in larger group }\end{array}$ \\
\hline $\begin{array}{l}\text { The subject } \\
\text { matter }\end{array}$ & $\begin{array}{l}\text { The results of } \\
\text { administrative performance }\end{array}$ & $\begin{array}{l}\text { Forms and procedures } \\
\text { to be implemented } \\
\text { using administrative } \\
\text { actions }\end{array}$ & $\begin{array}{l}\text { 1. Professional rules and } \\
\text { technical guidelines that } \\
\text { are implemented } \\
\text { 2. The results of } \\
\text { employees performance }\end{array}$ & $\begin{array}{l}\text { The results of } \\
\text { administrative } \\
\text { performance }\end{array}$ \\
\hline Criteria & $\begin{array}{l}\text { 1. Political criteria } \\
\text { 2. Objective and technical } \\
\text { criteria }\end{array}$ & $\begin{array}{l}\text { Formal criteria in rules } \\
\text { and procedures }\end{array}$ & $\begin{array}{l}\text { Professional criteria in } \\
\text { rules and technical } \\
\text { guidelines }\end{array}$ & $\begin{array}{l}\text { Social impact of } \\
\text { administrative } \\
\text { performance }\end{array}$ \\
\hline Mechanism & $\begin{array}{l}\text { 1. Internal supervision and } \\
\text { control mechanism (internal } \\
\text { responsibility) } \\
\text { 2. Parliamentary control } \\
\text { mechanism (external } \\
\text { responsibility) }\end{array}$ & $\begin{array}{l}\text { 1. External supervision } \\
\text { and control mechanism } \\
\text { 2. complaint } \\
\text { administration } \\
\text { 3. legal procedure }\end{array}$ & $\begin{array}{l}\text { 1. Internal supervision } \\
\text { and control mechanism } \\
\text { (technical or } \\
\text { administrative) } \\
\text { 2. External supervision } \\
\text { and control mechanism } \\
\text { (technical or } \\
\text { administrative) }\end{array}$ & $\begin{array}{l}\text { 1. Community } \\
\text { participation } \\
\text { mechanism } \\
\text { 2. Media or means of } \\
\text { aspiration for public } \\
\text { opinion } \\
\text { 3. Information } \\
\text { Technology }\end{array}$ \\
\hline Consequences & $\begin{array}{l}\text { 1. Political criticism or } \\
\text { appreciation } \\
\text { 2. Resignation and dismissal }\end{array}$ & $\begin{array}{l}\text { 1. Improvement of } \\
\text { administrative actions } \\
\text { (confirmation, } \\
\text { modification, } \\
\text { cancellation) } \\
\text { 2. Sanctions or rewards } \\
\text { for the head officials } \\
\text { 3. Compensation for the } \\
\text { community }\end{array}$ & $\begin{array}{l}\text { Sanctions or rewards } \\
\text { for the head officials }\end{array}$ & $\begin{array}{l}\text { 1. The adoption or } \\
\text { adjustment of } \\
\text { administrative actions } \\
\text { 2. Improvement of } \\
\text { administrative decisions } \\
\text { 3. The legitimacy of } \\
\text { democracy of } \\
\text { administrative } \\
\text { performance }\end{array}$ \\
\hline
\end{tabular}

The characteristics of accountability of Antonio Bar Cendon (1999) are used to analyze the implementation of ASN Employee Work Objectives (SKP) viewed from four aspects: a) Aspect of quantity / output (TO) in the form of documents, concepts, texts, decrees, and reports. The calculation of SKP achievements is based on the aspect of quantity by using the following formula:

Performance appraisal (SKP) $=\frac{\text { output realization }}{\text { output target }} \times 100$


b) Aspect of quality / Quality Target (TK) predicts the quality of the best work. Calculation of SKP achievements based on quality aspects using the following formula:

\begin{tabular}{|l|} 
Performance appraisal (SKP) $=\frac{\text { Quality realization (RK) }}{\text { Quality target (TK) }} \times 100$ \\
\end{tabular}

c) Time aspect / Time Target (TW) calculates how much time is needed to complete a job, for example one month, quarterly, quarterly, semester, 1 year. Evaluation of time aspects, is used to determine the percentage of time efficiency of the specified time target by using the following formula:

Percentage of time efficiency $=100 \%-\frac{\text { Time realization (RW) }}{\text { Time target }(\mathrm{TW})}$ ) $100 \%$

d) Cost aspect / Target Cost (TB) calculates how much it costs to complete a job in one year, for example millions, hundreds of millions, billions, and trillions. The assessment of cost aspects is used to determine the percentage of cost efficiency of the target cost by using the following formula:

$$
\begin{array}{|l|}
\hline \text { Percentage of cost efficiency }=100 \%-\frac{\text { Cost realization (RB) }}{\text { Cost target (TB) }} \text { x } 100 \% \\
\end{array}
$$

The assessment of achievement in SKP ASN is measured by comparing the realization with targets in terms of quantity, quality, time, and cost. The research conceptual framework is described in table 2. 


\section{Table 2. Conceptual framework}

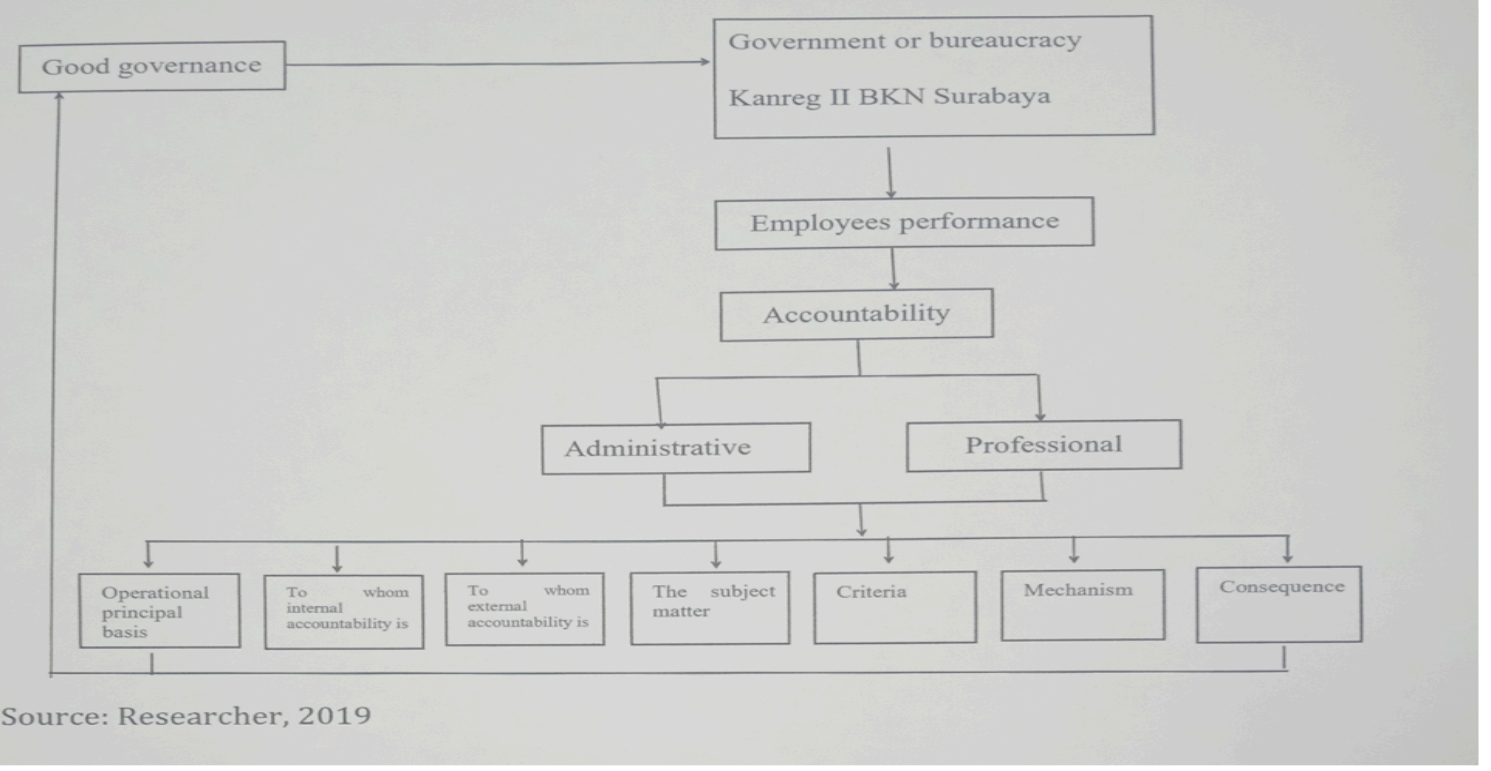

\section{METHODOLOGY}

This is a descriptive qualitative research, which focuses on the analysis of administrative and professional accountability consisting of basic operational principles, to whom internal accountability and external accountability are, subjects of affairs, criteria, mechanisms, and consequences in implementing SKP ASN in Kanreg II BKN Surabaya.

Primary data collection techniques with the key informants namely the Head of the Civil Service Supervision Kanreg II BKN Surabaya and Head of the Facilitating Performance Kanreg II BKN Surabaya which is done by using an observation. Meanwhile, the secondary data collection with supporting informants namely ASN in Kanreg II BKN Surabaya is done through interviews. Documentation data from secondary data is the SKP achievement assessment report from ASN Kanreg II BKN Surabaya which is based on Government Regulation No. 46 Year 2011 concerning Civil Servant Work Performance Assessment and Regulation of the Head of BKN 1/2011 regarding Provisions for Implementing Government Regulation No. 46 Year 2011, and Guidelines for the Work Target Assessment of Civil servants.

Data analysis techniques uses the interactive model of Milles and Hubberman (2014) which includes four stages from data collection, data condensation, data presentation, verification, and conclusion that can be seen in Figure 1. 
Figure 1: Data Analysis Components, Interactive Model

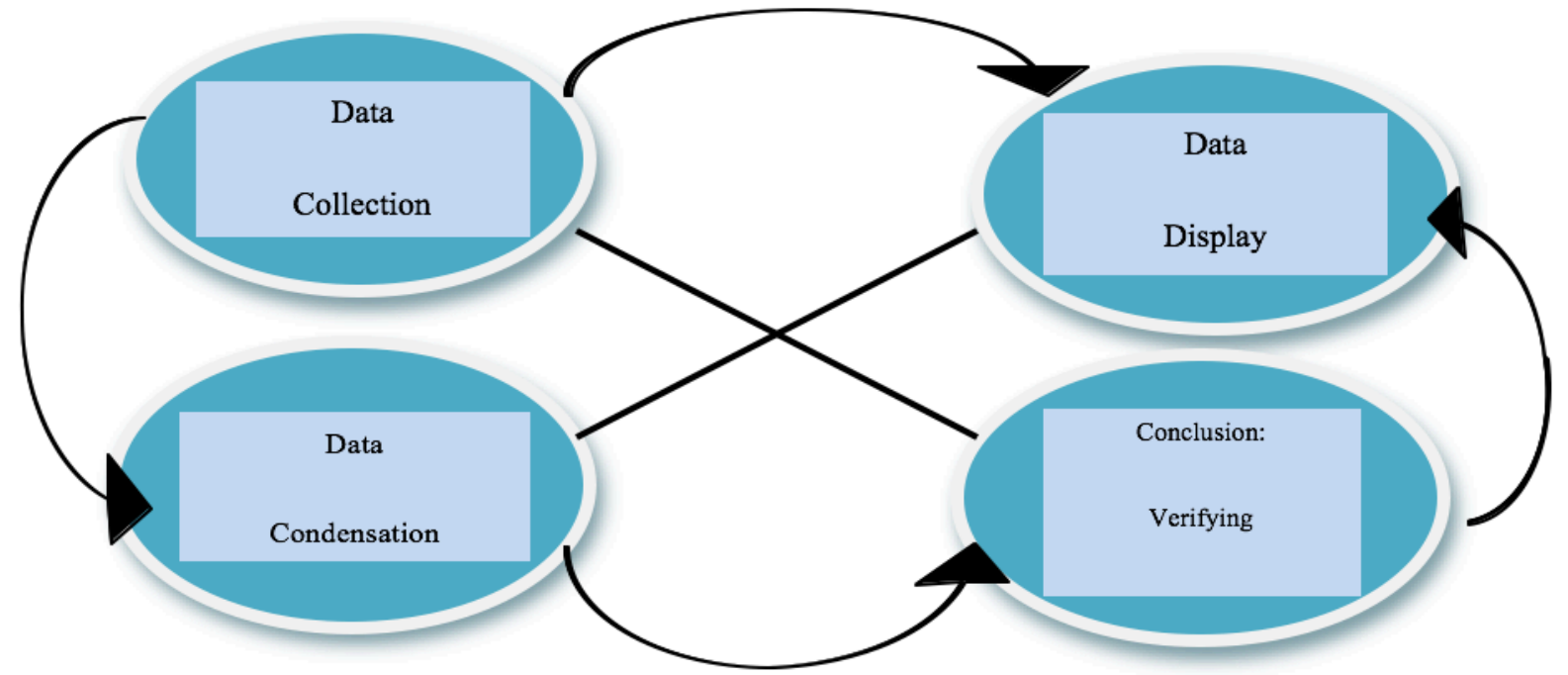

Sources: Milles, Huberman and Saldana (2014)

RESULTS AND DISCUSSION

The analysis of the operational principle basis indicators with legality and procedure subindicators as the character of administrative accountability shows that Government Regulation No. 46 Year 2011 concerning the Evaluation of Civil Servants' Work Performance as the main rule in the implementation of SKP. The indicator is based on the operational principles with sub-indicators of technical and practical rules according to the profession, namely Regulation of the Head of BKN 1/2013, Regulation of the Head of BKN 3/2016, and Permenpan RB. The results of the research indicate that the implementation of SKP in Kanreg II BKN Surabaya according to the indicators of operational principle basis, has the type of administrative and professional accountability supported by legality and procedures as well as the existence of technical and practical rules as guidelines in accordance with ASN profession.

The analysis of internal accountability indicators with sub-indicators of higher political authority as the character of administrative accountability in the implementation of SKP is the appraisal official. Furthermore, examining the authority of administrative institutions as characters of administrative and professional accountability in the implementation of SKP is Badan Kepegawaian Negara (BKN).

The results of the field study show that, based on internal accountability indicators, the implementation of SKP in Kanreg II BKN Surabaya has a type of administrative accountability that is supported by the higher political authority and higher authority of administrative institutions.

The Analysis of external accountability indicators with sub-indicators of supervision and control by external institutions as the character of administrative and professional accountability in the implementation of SKP is the inspectorate. The results of the field study indicate that, based on external accountability indicators, the implementation of SKP in Kanreg II BKN Surabaya has a type of professional accountability that is supported by the supervision and control by external institutions.

The Analysis of the subject matter indicators with sub-indicators of the existence of forms and procedures as the character of administrative accountability in the implementation of SKP shows Government Regulation No. 46 Year 2011 regarding the Performance Assessment of Civil Servants. Furthermore, examining the sub-indicators of professional rules and technical 
guidelines that are carried out as professional accountability characters in the implementation of SKP are the Regulation of the Head of BKN 1/2013, the Regulation of the Head of BKN $3 / 2016$, and Permenpan RB. The analysis of sub-indicators of performance results according to the field as a character of professional accountability in the implementation of SKP is the field of work, appointment and placement, development, appreciation and discipline.

The results of the field study showed that, based on the subject matter indicator, the implementation of employees performance in Kanreg II BKN Surabaya, had administrative and professional accountability types supported by the form of procedures, professional rules and technical guidelines as well as the results of performance according to the field.

The analysis of the indicator criteria with sub-indicators of conformity with the rules and procedures established as the character of administrative accountability in the implementation of SKP is Government regulation No. 46 Year 2011 concerning the Performance Assessment of Civil Servants. The analysis of the sub-indicators of conformity with the rules and technical guidelines established as professional accountability characters in the implementation of SKP, shows that the implementation of SKP in Kanreg II BKN Surabaya, is in accordance with the rules and technical guidelines namely Regulation of the Head of BKN 1/2013, Head Regulation 3/2016, and Permenpan RB.

The results of the field study show that, based on the criteria indicators, the Implementation of Employees Performance in Kanreg II BKN Surabaya, has administrative and professional accountability types that are supported by compliance with established rules, procedures and technical guidance rules.

The analysis of the mechanism indicators with external supervision sub-indicators and control mechanisms as characters of administrative and professional accountability in the implementation of SKP, is the inspectorate. The analysis of the mechanism indicators with the complaint administration sub-indicator as the character of administrative accountability in the implementation of SKP, is the administration of complaints in the Technical Standard Validation of SKP Activities regulated in the Regulation of the Head of BKN 3/2016. Admission of complaints in the results of work performance assessment is regulated in Government Regulation No. 46 Year 2011 and Regulation of the Head of BKN 1/2013. The analysis of mechanism indicators with legal procedure sub-indicators as the character of accountability in the implementation of SKP is Government Regulation No. 46 Year 2011, Regulation of the Head of BKN 3/2016, Regulation of the Head of BKN 1/2011. Further analysis of the sub-indicators of internal supervision and control mechanisms as a character of professional accountability in the implementation of SKP is the appraisal officer and the TIM PSTK SKP.

The results of the field study show that, based on mechanism indicators, the implementation of SKP in Kanreg II BKN Surabaya has a type of administrative accountability supported by the existence of complaints administration and legal procedures, internal supervision and control mechanisms.

The analysis of the consequence indicators with sub-indicators of sanctions or rewards for implementing officials as characters of administrative and professional accountability is that if the achievement of SKP at the end of the year is only $25 \%-50 \%$, the ASN will be disciplined while covering: a) delaying the periodic salary increase for one year, b) Postponement of rank increase for one year, c) Declining rank of one year lower. If the achievement of SKP at the end of the year is less than 25\%, the ASN will be subject to severe disciplinary action including: a) Downgrading to a lower level of three years b) Transferring in the context of lowering the 
position to a lesser degree, c) releasing from office, e) termination without respect for own request as ASN, f) Disrespectful dismissal as ASN. The analysis of consequences indicators with sub-indicators of improvement in administrative measures, is as a character of administrative accountability in the implementation of SKP and as guidance in the form of education and training.

The results of the field study show that, based on the consequence indicators, the implementation of the Employees Performance in Kanreg II BKN Surabaya has the type of administrative and professional accountability supported by sanctions and rewards to implement officials and improvement of administrative actions.

\section{CONCLUSION}

Based on the analysis and discussion conducted by the writer on the analysis of administrative and professional accountability in the implementation of employees performance in Kanreg BKN II Surabaya, the writer concludes that more dominant types of administrative and professional accountability as indicated by indicators of operational principle basis, subjects of affairs, criteria and mechanism. Furthermore, it can be seen from the sub-indicators that the dominant type of accountability is administrative accountability which has eleven characteristics while professional accountability has nine characteristics. Moreover, these results are inseparable from the existence of supporting factors in the suitability of administrative and professional accountability, namely regulation, supervision, application systems, definite descriptions of main tasks and functions, including the reward and sanctions.

Based on the results of research, the implementation of the Employees Performance has been accountable both administratively and professionally, so the researcher suggests that Kanreg II BKN Surabaya maintains what has been done. In addition, there are several suggestions from researchers to improve the implementation of Employees Performance.

1. Based on the observation of the researcher, Kanreg II BKN Surabaya can increase the understanding of civil servants by providing socialization and consultation regarding the preparation of SKP, especially in outlining the duties of employees' position.

2. Regulations are needed to set the assessment of employee work behavior, so that there is no subjectivity element of performance appraisal from the appraisal official.

3. It is necessary to make a new regulation from BKN regarding the Assessment of Work Performance to adjust to the existence of Law No. 5 Year 2014 concerning ASN.

4. For further researchers, they can adjust to the new rules, namely Law No. 5 Year 2014 concerning ASN, especially in article 75 and Government Regulation No. 49 Year 2018 concerning Management of Government Employees with Work Agreements in articles 76,77 , and 78 .

\section{BIBLIOGRAPHY}

Azhari. 2011. Mereformasi Birokrasi Publik. Yogyakarta: Pustaka Pelajar.

Bar Cendon, Antonio. 1999. Accountability and Public Administration: Concepts, Dimensions, Developments, Conference Proceedings, Openness and Transparency in Governance: Challenges and Opportunities, Maastricht. The Netherlands.

Bovens, M. 1998. The Quest for Responsibility: Accountability and Citizenship in Complex Organisations. Cambridge: Cambridge.

Dwivedi O.P. and J.G. Jabbra, Public Service Responsibility, dikutip M. Bovens, The Quest, Two concepts, juga dikutip B.S. Romzek, M.J. Dubnik, Accountability in the public sector.

Idrus, Muhammad. 2009. Metode Penelitian Ilmu Sosial, Pendekatan Kualitatif dan Kuantitatif, Penerbit Erlangga, Ciaracas - Jakarta. 
LAN dan BPKP. 2000. Akuntabilitas dan Good Governance. Jakarta: Lembaga Administrasi Negara.

Milles, Matthew B dan A. Michael Huberman. 1994. Analisa Data Kualitatif, Jakarta: Universitas Indonesia Press.

Prasojo, E., dan Kurniawan, Teguh. 2008. Reformasi Birokrasi dan Good Governance: Kasus Best Practices dari Sejumlah Daerah di Indonesia. Prosiding pada 5 th International Symposium of Jurnal Antropologi Indonesia, Banjarmasin.

Republik Indonesia, 1945. Undang - Undang Dasar.

Republik Indonesia. 2011. Peraturan Kepala Badan Kepegawaian Negara Nomor 34 Tahun 2011 tentang "Pedoman Penyusunan dan Penilaian Sasaran Kerja Pegawai dl Lingkungan Badan Kepegawaian Negara".

Republik Indonesia. 2011. Peraturan Pemerintah Nomor 46 Tahun 2011 tentang "Penilaian Prestasi Kerja Pegawai Negeri Sipil".

Republik Indonesia. 2013. Peraturan Kepala Badan Kepegawaian Negara Nomor 1 Tahun 2013 tentang "Ketentuan Pelaksanaan Peraturan Pemerintah Nomor 46 Tahun 2011 tentang Penilaian Prestasi Kerja Pegawai Negeri Sipil".

Republik Indonesia. 2016. Peraturan Kepala Badan Kepegawaian Negara Nomor 3 Tahun 2016 tentang "Pedoman Penyusunan Standar Teknis Kegiatan Sasaran Kerja Pegawai".

Sedarmayanti. 2010. Reformasi Administrasi Publik, Reformasi Birokrasi Dan Kepemimpinan Masa Depan. Bandung: PT. Rafika Aditama. 